\title{
Selection of sulfur oxidizing bacterium for sulfide removal in sulfate rich wastewater to enhance biogas production
}

\author{
Duangporn Kantachote* \\ Department of Microbiology \\ Faculty of Science \\ Prince of Songkla University \\ Hat-Yai 90112, Thailand \\ Tel: 6674288310 \\ Fax: 6674446661
}

E-mail: duangporn.k@psu.ac.th

\author{
Wilawan Charernjiratrakul \\ Department of Microbiology \\ Faculty of Science \\ Prince of Songkla University \\ Hat-Yai 90112, Thailand \\ Tel: 6674288324 \\ Fax: 6674446661 \\ E-mail:wilawan.c@psu.ac.th
}

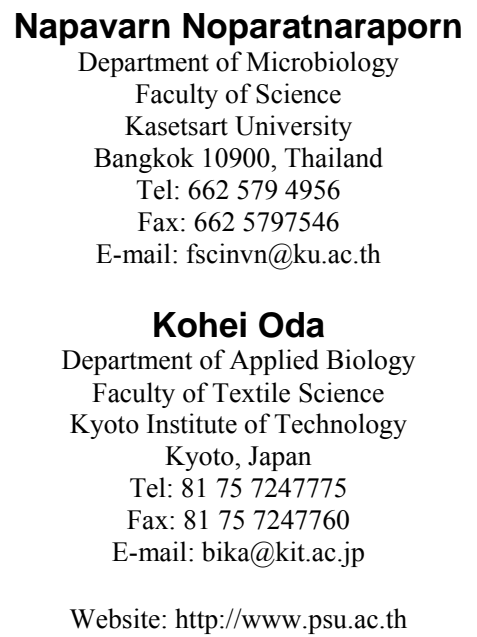

Financial support: This work was supported by the National Research Council of Thailand (NRCT) and Japan Society for the Promotion of Science (JSPS).

Keywords: biodesulfurization, biogas, effluent from a sulfate reduction reactor, sulfide.

Abbreviations: BOD: biochemical oxygen demand
COD: chemical oxygen demand
DS: dissolved sulfide
$\mathrm{H}_{2} \mathrm{~S}$ : hydrogen sulfide
MSM: mineral salts medium
MPB: methane producing bacteria
ROW: raw optimized wastewater
SOB: sulfur oxidizing bacteria
SOW: sterile optimized wastewater
SRB: sulfate reducing bacteria
SRR: a sulfate reduction reactor
SEM: scanning electron microscope
TKN: total Kjeldahl nitrogen
TS: total sulfide
TSY: thiosulfate yeast extract medium
UASB: upflow anaerobic sludge blanket
VFAs: volatile fatty acids


Sulfur oxidizing bacteria (SOB) were isolated and tested in order to remove sulfide from high sulfate wastewater to reduce the amount of hydrogen sulfide $\left(\mathrm{H}_{2} \mathrm{~S}\right)$ in the produced biogas. A promising SOB isolate, designated as isolate T307, was selected due to its best sulfide removal $(86.7 \%)$ in the effluent of a sulfate reduction reactor (SRR) over a 24 hrs incubation. The bacterium was able to grow better as a mixotroph (yeast extract as a carbon source) than as a chemolithoautotroph. In addition, as a heterotroph, the bacterium grew well with yeast extract and peptone. Based on partial 16S rRNA gene sequence, the isolated T307 was an Alcaligenes sp. and was able to convert most of sulfide species (total sulfide: TS; dissolved sulfide: DS and $\mathrm{H}_{2} \mathrm{~S}$ ) into elemental sulfur or sulfate over a $20 \mathrm{hrs}$ period of cultivation by controlling the speed of shaking. In a biogas reactor set, after pre-treating a sulfide medium with Alcaligenes sp. T307 there was a much higher specific yield of $\mathrm{CH}_{4}\left(238 \mathrm{ml} \mathrm{CH}_{4} \mathrm{~g}^{-1} \mathrm{COD}\right.$ removed) and more biogas $\left(154 \mathrm{ml} \mathrm{L}^{-1} \mathrm{~d}^{-1}\right)$ was produced with the biogas containing more methane $\left(48.1 \% \mathrm{CH}_{4}, 51.5 \%\right.$ $\mathrm{CO}_{2}$ and $0.41 \% \mathrm{H}_{2} \mathrm{~S}$ ) in comparison to a control with a specific yield of $\mathrm{CH}_{4},\left(72 \mathrm{ml} \mathrm{CH}_{4} \mathrm{~g}^{-1} \mathrm{COD}\right.$ removed) 86 $\mathrm{ml} \mathrm{L}^{-1} \mathrm{~d}^{-1}$ biogas produced with a composition of $35.5 \%$ $\mathrm{CH}_{4}, 63.7 \% \mathrm{CO}_{2}$ and $0.86 \% \mathrm{H}_{2} \mathrm{~S}$.

There are numerous latex rubber factories in southern Thailand and anaerobic treatment, particularly in lagoons, is the most commonly used process for treating their wastewater (Kantachote et al. 2005). The anaerobic wastewater system provides many advantages such as, a low cost operation with high efficiency and also with the possibility of producing a useful energy source biogas; however, sulfide is generated during anaerobic treatment of high sulfate wastewater, a characteristic of wastewater from rubber factories. An advanced system such as the sulfate reduction reactor (SRR) has been used to treat sulfate rich rubber wastewater from processes of concentrated latex and skim crape (Tekasakul and Tekasakul, 2006). However, high sulfide levels are produced due to sulfate being used as a terminal electron acceptor in anaerobic respiration. The SRR is a step to reduce sulfate concentration in wastewater prior to transferring the wastewater to an UASB (upflow anaerobic sludge blanket) for obtaining biogas as a byproduct. Nevertheless, biogas produced from both the SRR and the UASB do not meet the standard of biogas composition because of their high contaminations of $\mathrm{H}_{2} \mathrm{~S}$. Therefore, the biogas was burnt to remove the very toxic and corrosive $\mathrm{H}_{2} \mathrm{~S}$ gas that has a very low odor threshold of $1 \mu \mathrm{g} \mathrm{L}^{-1}$ (Oyarzun et al. 2003). Hence, introducing one more step to convert sulfide to sulfur by partial oxidation instead of by completely oxidizing it to sulfate could be an interesting alternative method for solving this problem. It is realized that levels of sulfide oxidation are dependent on oxygen concentration (Gonzalez Sanchez et al. 2005). It has long been recognized that bacteria able to oxidize reduced sulfur compounds can be used to remove contaminating
$\mathrm{H}_{2} \mathrm{~S}$, from either treated wastewater or gaseous systems (Sublette et al. 1998; Cha et al. 1999; Kleerebezem and Mendez, 2002; Chung et al. 2003). Removal of $\mathrm{H}_{2} \mathrm{~S}$ from any SRR effluent, would greatly improve the economics of the process, particularly if this could be achieved microbiologically. It is therefore of importance to select a microbe that can grow well at ambient temperatures and neutral $\mathrm{pH}$ and oxidize sulfide to sulfur in wastewater. Our previous studies have reported on the potential use of a Thiobacillus sp. for treating latex rubber sheet wastewater (Kantachote and Innuwat, 2004). Hence, this work is focused on the isolation and identification of a bacterium able to oxidize sulfide to sulfur in sulfate rich wastewater to achieve our goal of obtaining a better and more efficient production of biogas during the treatment of wastewater from rubber manufacturing plants.

\section{MATERIALS AND METHODS}

\section{Isolation and selection of a sulfide oxidizing bacterium}

Strains of Thiobacillus sp. were isolated from sulfide rich wastewater samples collected from rubber factories in southern Thailand using a thiobacillus isolation medium named thiosulfate mineral salts medium (thiosulfate MSM). The medium composition in $1 \mathrm{~L}$ of distilled water is $2.0 \mathrm{~g}$ $\mathrm{KNO}_{3}, 1.0 \mathrm{~g} \mathrm{NH}_{4} \mathrm{Cl}, 2.0 \mathrm{~g} \mathrm{KH}_{2} \mathrm{PO}_{4}, 2.0 \mathrm{~g} \mathrm{NaHCO}_{3}, 0.8 \mathrm{~g}$ $\mathrm{MgSO}_{4} .7 \mathrm{H}_{2} \mathrm{O}$, 5.0 g Na $\mathrm{S}_{2} \mathrm{O}_{3} .5 \mathrm{H}_{2} \mathrm{O}$ and $1.0 \mathrm{ml}$ trace element solution with the $\mathrm{pH}$ adjusted to 6 with $1 \mathrm{~N} \mathrm{KOH}$. In some situations the thiosulfate was replaced by $5.0 \mathrm{~g}$ $\mathrm{Na}_{2} \mathrm{~S} .9 \mathrm{H}_{2} \mathrm{O}$ and principle for this replacement is to acclimate the SOB for utilizing sulfide in a SRR effluent. The trace element solution contained in $1 \mathrm{~L}$ of distilled water: $50 \mathrm{~g} \mathrm{Na}$-EDTA, $7.34 \mathrm{~g} \mathrm{CaCl}_{2} .2 \mathrm{H}_{2} \mathrm{O}$, $5.0 \mathrm{~g}$ $\mathrm{FeSO}_{4} .7 \mathrm{H}_{2} \mathrm{O}, 2.5 \mathrm{~g} \mathrm{MnCl}_{2} .4 \mathrm{H}_{2} \mathrm{O}, 2.2 \mathrm{~g} \mathrm{ZnSO}_{4} .7 \mathrm{H}_{2} \mathrm{O}, 0.5 \mathrm{~g}$ $\left(\mathrm{NH}_{4}\right)_{6} \mathrm{Mo}_{7} \mathrm{O}_{24} \cdot 4 \mathrm{H}_{2} \mathrm{O}, 0.2 \mathrm{~g} \mathrm{CaSO}_{4} .5 \mathrm{H}_{2} \mathrm{O}$ and $11.0 \mathrm{~g} \mathrm{NaOH}$ (DSMZ, 2002). $15 \mathrm{~g}$ of agar was added to solidly the medium. Five $\mathrm{ml}$ of the wastewater samples were added to a shaking flask containing $50 \mathrm{ml}$ of the MSM and incubated in a rotary shaker $(100 \mathrm{rpm})$ at $30^{\circ} \mathrm{C}$ for 7 days. The development of turbidity in the medium was assumed to be due to bacterial growth and any flask that also showed a $\mathrm{pH}$ drop indicating the growth of thiobacilli was chosen for purification by streaking onto the thiosulfate MSM solid medium, also incubated at $30^{\circ} \mathrm{C}$ for 7 days. The purified cultures were initially screened by growing in the MSM containing $\mathrm{Na}_{2} \mathrm{~S}$ instead of $\mathrm{Na}_{2} \mathrm{~S}_{2} \mathrm{O}_{3}$. Strains that grew well in sulfide medium as the sole source of energy were further screened by using a SRR effluent as a medium without any supplementation but after it had been centrifuged at 6455 (RCF $\mathrm{x} \mathrm{g}$ ) for $10 \mathrm{~min}$ and sterilized at $121^{\circ} \mathrm{C}$ for $15 \mathrm{~min}$. Parameters of the SRR effluent were (mg L $\left.{ }^{-1}\right)$ : BOD 500, COD 2050, TKN 198 (total Kjeldahl nitrogen) and the $\mathrm{pH}$ was 7.88. The criteria used for selecting an appropriate sulfide oxidizing bacterium for further study was based on the one producing the highest rate of sulfide removal from

*Corresponding author 
the SRR effluent. Each experiment in this step was conducted in three replicates.

\section{Identification of SOB}

The SOB selected, isolate T307, was identified using morphological, physiological and biochemical properties according to Bergey's Manual of Systematic Bacteriology, vol. 3 (Kelly and Harrison, 1989). A scanning electron microscope (SEM), model JSM-5800LV, JEOL was used to examine morphology and size of bacterial cells and the protocol used for SEM followed the instruction manuals for the instrument. Bacterial properties investigated were catalase, oxidase, growth conditions at 4 and $42^{\circ} \mathrm{C}$ and growth as a facultative anaerobe. For these tests bacterial cells were grown in thiosulfate MSM. Heterotrophic growth of a selected strain was determined using the thiosulfate MSM, in which $\mathrm{Na}_{2} \mathrm{~S}_{2} \mathrm{O}_{3}$ was replaced with each organic compound added at a concentration of $0.1 \%(\mathrm{w} / \mathrm{v})$. The following organic compounds were tested, yeast extract, peptone, sucrose, fructose, lactose, maltose, mannitol, starch, arginine, sodium acetate and sodium formate. In addition, the API 20E assay (a commercial test kit for the identification of Enterobacteriaceae and other Gram negative bacteria) was carried out in parallel according to the manufacturer's instructions (BioMerieux, Marcy I'Etoile, France) at $30^{\circ} \mathrm{C}$. Mixotrophic growth of the selected strain was investigated in the thiosulfate MSM by amending with $0.05 \%$ (w/v) yeast extract (Chen et al. 2004) and observing any increase in growth compared with that in the normal thiosulfate MSM. Sulfate production resulting from bacterial growth was observed by measuring the initial and the final sulfate concentration of the culture broth. In order to obtain a high cells density, a thiosulfate medium for Thiobacillus sp. IW (Park et al. 2002) was modified by adding $0.1 \%(\mathrm{w} / \mathrm{v})$ yeast extract instead of $0.2 \%(\mathrm{w} / \mathrm{v})$ for preparation of the inoculants and this medium was named as thiosulfate yeast extract medium (TSY). This was used for the inoculum to test cultures for their ability to remove sulfide from a SRR effluent and also for identification purposes and for determining the effects of $\mathrm{pH}(2-9)$ and temperature $\left(25-40^{\circ} \mathrm{C}\right)$ on bacterial growth. The specific growth rate was determined during exponential growth for each $\mathrm{pH}$ and temperature. Bacterial growth was measured as turbidity using a spectrophotometer at optical density $660 \mathrm{~nm}$, whereas the standard plate count method was used to count viable cells. 16S rRNA gene sequence (500 base pairs) was also carried out to identify the selected isolate. Genomic DNA was extracted using the standard method and then amplified by GeneAmpPCR system 9600 according to Altschul et al. (1997) followed by a homology search with BLASTn program from the NCBI database. Alignment and production of a phylogenetic tree was obtained using the DNASIS V3.7 program, the unweighted pair-group method using arithmetic averages (UPGMA) was also used.

\section{Analytical procedures}

The following methods used in this study are described in the APHA, AWWA and WPCF (1998). Sulfide was measured in three forms as TS, DS and un-ionized hydrogen sulfide $\left(\mathrm{H}_{2} \mathrm{~S}\right)$ using an iodometric method, whereas sulfate was determined using a turbidimetric method. $\mathrm{BOD}_{5}$ was measured by the azide modification method, COD (chemical oxygen demand) by the dichromate reflux method, and TKN using the Kjeldahl method. In addition, volatile fatty acids (VFAs) were examined by the direct titration method and it was calculated in a form of acetic acid. A pH meter was used to measure $\mathrm{pH}$.

\section{Inoculum preparation}

An actively growing culture of a selected SOB isolate, T307, from a thiosulfate MSM agar slant was subcultured in $10 \mathrm{ml}$ TSY in a test tube and incubated under optimum

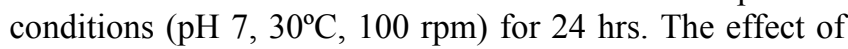
shaking speed on bacterial growth was investigated in our preliminary studies when $100 \mathrm{rpm}$ provided maximal growth and a high cell density. Consequently a $10 \%$ inoculum of this culture broth was transferred to $100 \mathrm{ml}$ TSY in an Erlenmeyer flask and incubated under the same conditions for $10 \mathrm{hrs}$ to produce exponentially growing cells and used as inoculants.

\section{Sulfide removal in the effluent from SRR}

Effluent collected from an SRR at Chalong latex industry, Co, Ltd. in Songkhla province, Thailand, was used in this study without amendment, except the effluent was first centrifuged at $6455(\mathrm{RCF} \times \mathrm{g}$ ) for $10 \mathrm{~min}$ and the initial $\mathrm{pH}$ was adjusted to 7 . Different batches of SRR effluent were used in step of isolation and this experiment. Treatment consisted of 2 sets, of $1 \mathrm{~L}$ glass bottles fitted with a plastic cap and filled with $800 \mathrm{ml}$ of either sterile optimized wastewater (SOW) or raw optimized wastewater (ROW) in each bottle. Each treatment set was inoculated with a $10 \%$ inoculum of the selected SOB isolate T307, therefore the SOW set contains a pure culture and the ROW set a mixed culture of indigenous microbes and the selected SOB isolate. The culture bottles were incubated at $30^{\circ} \mathrm{C}$ with 70 rpm (this shaking speed was chosen because it provided partial oxidation of sulfide to sulfur as a yellow precipitation was found in our preliminary study using a shaking speed of $70 \mathrm{rpm}$ ). Parameters: BOD (biochemical oxygen demand), COD, VFAs, viable cells, $\mathrm{pH}$, TS, DS, $\mathrm{H}_{2} \mathrm{~S}$ and sulfate were monitored at the beginning $(\mathrm{t}=0)$ and the end (20 hrs) of the experiment. The experiment was conducted in three replicates.

\section{Biodesulfurization prior to biogas production}

At about this time when we were about to confirm our results of the removal of sulfide from a SRR effluent, unfortunately the factory producing the SRR faced a 
problem with low efficiency of the SRR and sulfide levels were not sufficiently high. Consequently, the thiosulfate MSM was modified by replacing sodium thiosulfate with sodium sulfide $\left(\mathrm{Na}_{2} \mathrm{~S} .9 \mathrm{H}_{2} \mathrm{O}: 5 \mathrm{~g} \mathrm{~L}^{-1}\right)$. Biodesulfurization was performed in $800 \mathrm{ml}$ of the sulfide broth in a bioreactor with a $10 \%$ inoculum of the selected SOB inoculant T307 and incubated at $30^{\circ} \mathrm{C}$ and $70 \mathrm{rpm}$ for $20 \mathrm{hrs}$. A control abiotic set without inoculation was also conducted. The following parameters: $\mathrm{pH}$, viable cells, TS, DS, $\mathrm{H}_{2} \mathrm{~S}$ and sulfate were monitored at zero time and after $20 \mathrm{hrs}$ incubation. Four replicates were set in this experiment. In this study, a sulfur balance was not determined due to the volatilization of sulfide as $\mathrm{H}_{2} \mathrm{~S}$ during the autoclaving that provided sterile conditions.

\section{Biogas production}

$1 \%$ sodium acetate was added to the sulfide MSM bottles containing the $900 \mathrm{ml}$ of culture broth, pre-treated with the SOB isolate, T307. This was to test for the production of biogas by methane producing bacteria (MPB). $100 \mathrm{ml}$ of seed sediment inoculum from an anaerobic rubber wastewater treatment plant was then added prior to the start of sampling for COD determinations. The inoculum comprised both sulfate reducing bacteria (SRB) and MPB. A control set was prepared at the same but using the uninoculated set bottles from the previous experiment. This biogas fermentation experiment was set up as presented in Figure 1 and the biogas fermentation was conducted at room temperature $\left(30 \pm 3^{\circ} \mathrm{C}\right)$. The volume of biogas produced was measured by the water displaced. The Biogas composition was measured from the headspace gas of the biogas fermentation bottles using a portable multi gas detector (Oldham MX 2100) according to the instruction manuals. The biogas fermentation was run for 5 days as at this time gassing had slowed in a control set. The liquid was centrifuged at 6455 (RCF $\times \mathrm{g}$ ) for $15 \mathrm{~min}$ and then used to determine the following parameters: $\mathrm{pH}, \mathrm{TS}, \mathrm{DS}$, $\mathrm{H}_{2} \mathrm{~S}$, sulfate, and COD. A specific yield of $\mathrm{CH}_{4}$ was calculated based on the COD removed. This experiment was repeated twice and each time in triplicate.

\section{RESULTS}

\section{Isolation and selection of SOB}

A total of 147 isolates were obtained from a variety of latex wastewater treatment plants; however, only 63 isolates $(42.9 \%)$ were able to oxidize sulfide and following screening by inoculation into a SRR effluent, 22 isolates grew, but only 11 isolates grew well (data not shown). Based on the removal of sulfide, an isolate T307 was chosen as it gave the highest reduction $(86.7 \%)$ in a sample of the SRR effluent over a $48 \mathrm{hrs}$ cultivation period. Even at $24 \mathrm{hrs}$ the slightly lower percentage reduction was not significantly different from that at $48 \mathrm{hrs}$ (Figure 2).

\section{Identification of SOB}

Isolate T307 was a Gram negative, non motile, short rod, with average dimensions of $0.5 \times 0.9 \mu \mathrm{m}$ (Table 1) that formed round smooth and white colonies with an average diameter of $0.5 \mathrm{~mm}$ on the thiosulfate MSM agar plate. Catalase and oxidase tests were both positive. The isolate T307 grew under both aerobic and anaerobic conditions in which sodium thiosulfate was present. Chemolithotrophic aerobic growth of isolate T307 was found on sulfide and thiosulfate salt. Heterotrophic growth occurred with yeast extract, peptone, urea and gelatin. No growth was observed with any of the other selected single organic compounds except for acetate and formate but growth was poor. Mixotrophic growth was demonstrated on the thiosulfate MSM plus $0.05 \%$ yeast extract and as an increased amount of sulfate over the thiosulfate MSM control was detected at the end of growth (data not shown), indicating that thiosulfate was being used as an energy source. The isolate T307 grew better as a heterotroph especially with yeast extract and peptone rather than as a chemolitrotroph or mixotroph (Table 2). The $\mathrm{pH}$ range for growth was from 5 to 9 (maximal pH tested) with an optimum at $\mathrm{pH} 7.0$ and over a temperature range of $4-42^{\circ} \mathrm{C}$ with an optimal of 25 $30^{\circ} \mathrm{C}$. More details of the properties of the isolate T307 are shown in Table 1.

According to the conventional methods used in Table 1, the isolate T307 could be either an Alcaligenes sp. or Thiobacillus delicatus (Kersters and Ley, 1984; Kelly and Harrison, 1989). However, some key characteristics of the isolate T307 were different from both organisms such as motility (Alcaligenes: motile) and oxidase (T. delicatus: negative). Therefore, a partial 16S rDNA analysis was used to help in a decision and its accession number, AY 628412, for the 16s rRNA gene sequence of the isolate T307 was $100 \%$ similar to that of Alcaligenes sp. YcX-20, and $87.2 \%$ to $A$. faecalis strain ITRC EM2. The isolate T307 was therefore named Alcaligenes sp. T307 (Figure 3).

\section{Sulfide removal}

Alcaligenes sp. T307 was able to remove all forms of sulfide from a SRR effluent: $91.84 \%$ TS, $88.75 \%$ DS and $95.76 \% \mathrm{H}_{2} \mathrm{~S}$, whereas with a mixture of indigenous microbes the removal was significantly lower at $56.24 \%$ TS, $32.29 \%$ DS and $92.11 \% \mathrm{H}_{2} \mathrm{~S}$ (Table 3). Some yellow precipitation was found in both treatments with most in the SOW set. At the end of the experiment, more viable cells were detected $(0.2 \log$ cycle) in a ROW set than that in a SOW set even though the initial cell count was lower and the $\mathrm{pH}$ was also higher, $(\mathrm{pH} 8.52$ compared with 8.29). This is consistent with the higher growth observed in the presence of yeast extract. In contrast, reduction of VFAs was significantly higher in a ROW set than in a SOW set. There was no significant difference in the $\mathrm{BOD} / \mathrm{COD}$ ratios 
and also the sulfate levels between the SOW and ROW sets at either the start or end of the experiment (Table 3).

\section{Biodesulfurization prior to biogas production}

Very little change occurred in the monitored parameters $\left(\mathrm{pH}, \mathrm{TS}, \mathrm{DS}, \mathrm{H}_{2} \mathrm{~S}\right.$ and sulfate) in the uninoculated set (abiotic control). In contrast, there was a big decrease of sulfide species observed in the sulfide medium inoculated with Alcaligenes sp. T307, particularly the percentage loss of TS 83.22, DS 71.78 and $\mathrm{H}_{2} \mathrm{~S} 90.41 \%$. Bacterial cells increased from $8.36 \log \mathrm{cfu} \mathrm{L} \mathrm{L}^{-1}$ to $9.72 \log \mathrm{cfu} \mathrm{L}^{-1}$ over the $20 \mathrm{hrs}$ of incubation and the $\mathrm{pH}$ increased from 7.33 to 8.44 as a result of bacterial growth. There was virtual no increase in sulfate (Table 4).

\section{Biogas production}

$1 \%$ acetate was added to the sulfide medium pre-treated by Alcaligenes sp. T307 (T307) for $20 \mathrm{hrs}$ to remove sulfide, to test for biogas production. The experiment was repeated twice. In both cases the average amount of biogas after treatment with $\mathrm{T} 307\left(240 \mathrm{ml} \mathrm{L}^{-1} \mathrm{~d}^{-1}\right)$ was significantly higher than that of the control $\left(86 \mathrm{ml} \mathrm{L}^{-1} \mathrm{~d}^{-1}\right)$. The biogas composition as a percentage in a set pre-treated by $\mathrm{T} 307$ was $\mathrm{CH}_{4} 48.06 \pm 7.15, \mathrm{CO}_{2} 51.53 \pm 7.18$ and $\mathrm{H}_{2} \mathrm{~S} 0.41 \pm$ 0.30 , whereas in the control set percentage $\mathrm{CH}_{4}$ was 35.47 $\pm 12.99, \mathrm{CO}_{2} 63.67 \pm 13.29$ and $\mathrm{H}_{2} \mathrm{~S} 0.86 \pm 0.69$. Reduction of COD in the biogas reactors pre-treated by T307 was $49.6 \%$, while in the control set it was $36.6 \%$. The specific yield of $\mathrm{CH}_{4}$ produced per COD removed was $238 \mathrm{ml} \mathrm{CH}_{4}$ $\mathrm{g}^{-1}$ in the set pre-treated by T307 whereas in the control set it was only $71.53 \mathrm{ml} \mathrm{CH}_{4} \mathrm{~g}^{-1}$. More details on the properties of the sulfide media such as levels of sulfide species and sulfate are shown in Table 5.

\section{DISCUSSION}

\section{Isolation and selection of SOB}

In general, the thiosulfate MSM used in this study is normally used to isolate pure cultures of Thiobacillus sp. or other obligate chemolithoautotrophic sulfide oxidizing bacteria. Thiosulfate is stable at neutral $\mathrm{pH}$, easily soluble and non toxic at a high concentration (Kuenen et al. 1992). Although the isolate T307 obtained in this study closely resembled Thiobacillus delicatus (Table 1, presently Thiomonas delicata, Katayama et al. 2006) it was eventually identified as an Alcaligenes sp. based on its rDNA properties and named Alcaligenes sp.T307. It was isolated from a sample of wastewater obtained from a rubber treatment plant. The results of this study prove that the ability to oxidize sulfide is a property of Alcaligenes sp. T307. There has been other reports that Alcaligenes species can grow with sulfur compounds as an energy source (Kersters and Ley, 1984; Moreira and Amils, 1997) and it was also supported by Potivichayanon et al. (2006) who reported that Acinetobacter sp. MU1_03 and Alcaligenes faecalis MU2_03 in a fixed-film bioscrubber system were able to remove hydrogen sulfide more than $91 \%$ while a mixture of the two strains was capable of $98 \%$ hydrogen sulfide removal. Hence based on our results, metabolic capacity, together with rod morphology cannot be considered as useful taxonomic criteria for inclusion of any new species in the genus Thiobacillus. This is supported by Moreira and Amils (1997) and Van Trappen et al. (2005) who reported that the mixotrophic Thiobacillus organisms form a phylogenetic cluster within the $\beta 1$ subgroup of the Proteobacteria (Alcaligenes faecalis, Alcaligenes sp., Burkhoderia cepacia, Thiobacillus intermedius and $T$. perometabolis). In addition, the isolate $\mathrm{T} 307$ had a $100 \%$ similarity index with Alcaligenes sp. YcX-20, a methylparathion degrading bacterium, as reported by Jiang et al. (2005). The $16 \mathrm{~S}$ rDNA analysis (500 bp) of the isolate T307 corresponded with that $A$. faecalis strain ITRC EM2 (87.2\% homology). It is clear that an apparently close match in $16 \mathrm{~S}$ rDNA analysis is not sufficient to indicate species identity, but that at least $70 \%$ DNA homology is required. Therefore, complete 16S rRNA gene sequence and DNA-DNA hybridization between the selected isolate T307 and related Alcalignes faecalis will be conducted to prove that the isolate T307 may be a novel species of the genus Alcaligenes.

\section{Sulfide removal by Alcaligenes sp. T307}

As the $\mathrm{BOD} / \mathrm{COD}$ ratios in the two sets of experiments (SOW and ROW) used to determine the removal of sulfide, both before and after culture, were between 0.20-0.38 (Table 3) this meant that the nutrient composition was suitable for mixotrophic rather than heterotrophic growth. Previously, Bitton, (2005) has established that a BOD/COD ratio in the range of $0.40-0.80$ is required to support heterotrophic growth. The increase in viable cells resulting from the addition of yeast extract (Table 2) indicates that Alcaligenes sp. T307 can grow as a mixotroph. The observed changes in the different forms of sulfide have therefore occurred during growth of the microbes as mixotrophs. The presence of the organic matter might affect this process when the microbes have to grow as a chemolithotroph.

The results presented in Table 3 indicate that Alcaligenes sp. T307 in pure culture was better at removing all forms of sulfide than when it was present together with indigenous microbes. A possible explanation could be that in the ROW set, T307 has to compete with some indigenous microbes less effective sulfide oxidizing microbes (e.g. Table 1) for some essential nutrient. The indigenous microbes may also be able to utilize the VFAs for growth whereas the ability of T307 is restricted (Table 3). This may also account for the increased removal of VFAs $\left(28 \mathrm{mg} \mathrm{L}^{-1} \mathrm{SOW}, 107 \mathrm{mg}\right.$ $\mathrm{L}^{-1}$ for ROW) and growth observed in a ROW set ( $0.61 \mathrm{cfu}$ $\mathrm{ml}^{-1}$ in SOW compared to $0.80 \mathrm{cfu} \mathrm{ml}{ }^{-1}$ for ROW). Removal of sulfide and VFAs from the medium will cause a rise in $\mathrm{pH}$ but this requires the presence of bacteria. The increase in $\mathrm{pH}$ was slightly bigger with ROW than SOW due mainly to the bigger loss of VFAs. It is well known that 
$\mathrm{pH}$ alters the forms of sulfide $\left(<7: \mathrm{H}_{2} \mathrm{~S}, 7-9\right.$ : $\mathrm{HS}^{-}$and $>8$ : $\mathrm{S}^{2-}$ ) (Markl, 1999), so this also may have some effect on the process. As mentioned above sulfide removal was satisfactorily high for SOW and not for ROW. However, due to the fact that the most toxic form of sulfide is $\mathrm{H}_{2} \mathrm{~S}$, the results showed the isolate T307 gave a high efficiency to remove $\mathrm{H}_{2} \mathrm{~S}$ (92-96\%) both in ROW and SOW. Therefore, the less toxicity of sulfide, the more MPB could grow. In both cases some precipitation of elemental sulfur occurred, slightly more in SOW. This is due to the partial oxidation of reduced $\mathrm{S}$ compounds as there was virtually no change in the sulfate levels. As there was no precipitation in the control, without added organisms, its formation was also being catalyzed by the bacteria. The increased amount in the SOW set could be due to a higher population of T307, a lower $\mathrm{pH}$ or the presence of slightly more $\mathrm{O}_{2}$. In both cases it is likely that $\mathrm{O}_{2}$ levels were limiting. It is possible that the shaking speed of only $70 \mathrm{rpm}$ used in this experiment may limit the amount of oxygen, thereby restricting complete oxidation to sulfate. It is known that the oxidation of several sulfide species to elemental sulfur and sulfate can be controlled by oxygen levels (Gonzalez Sanchez et al. 2005).

Comparing the growth in the SRR-SOW set with that in the sulfide medium, over the $20 \mathrm{hrs}$ incubation (Table 3 and Table 4) viable cells increased by $1.36 \log \mathrm{cfu} \mathrm{ml}^{-1}$ in the sulfide medium, whereas in the SRR - SOW set, the increase was only $0.61 \log \mathrm{cfu} \mathrm{ml}^{-1}$. This means some growth inhibitors may have been present in the SRR effluent. Therefore, rates of sulfide removal in the sulfide medium were significantly higher $\left(3 \mathrm{mg} \mathrm{L}^{-1} \mathrm{~h}^{-1}\right)$ than that in the SRR-SOW set $\left(0.90 \mathrm{mg} \mathrm{L}^{-1} \mathrm{~h}^{-1}\right)$ due to a higher viable cell of the isolate T307 in the sulfide medium.

\section{Biogas production}

After removal of sulfide by pre-treating sulfide medium with $\mathrm{T} 307$, biogas production was significantly increased and contained a higher proportion of methane. During the 5 days incubation period, there are 3 parameters that have to be considered as likely to affect biogas production: changes in sulfide species, sulfate levels and COD (Table 5). It has long been known that in a biogas reactor the relative amounts of SRB and MPB affect the amount and composition of biogas (Santegoeds et al. 1999). Sulfate is utilized as a terminal electron acceptor by SRB and the generation of sulfide inhibits MPB due to sulfide toxicity (Khanal and Huang, 2003). The higher levels of sulfide species in the control set could inhibit MPB causing a 12 hrs delay in biogas production (data not shown) with the MPB able to catalyze only weak methanogenic activity. The lower amount of sulfate found in the control set, after 5 days, indicates that some sulfate was being consumed by $\mathrm{SRB}$, and initially these may be the dominant organisms (Table 4 and Table 5). As the percentage of COD removal in the control was lower (13\%) than after the treatment with T307 this may indicate that the higher sulfide levels produced by SRB also inhibited COD removal.
In conclusion, results in this study indicate that MPB were strongly inhibited by sulfide produced by SRB in a sulfate rich wastewater. Therefore biodesulfurization is an important step for the effluent from wastewater with high sulfate prior to a step for producing biogas. Alcaligenes sp. T307 has the potential to use in a step of biodesulfurization.

\section{ACKNOWLEDGMENTS}

We would like to thank Dr Brian Hodgson for fruitful discussion. We also thank Chalong latex industry Co, Ltd. and P.S. Rubber Company for giving wastewater and seed sediment inoculum.

\section{REFERENCES}

ALTSCHUL, S.F.; THOMAS, L.M.; ALEJANDRO, A.S.; JINGHUI, Z.; ZHENG, Z.; WEBB, M. and LIPMAN, D.J. Gapped BLAST and PSI-BLAST: a new generation of protein databases search program. Nucleic Acids Research, 1997, vol. 25, no. 17, p. 3389-3402.

APHA, AWWA and WPCF. Standard Method for Examination of Water and Wastewater $20^{\text {th }}$ ed. Washington, D.C. American Public Health Association, 1998, 1325 p. ISBN 0-87553-235-7.

BITTON, Gabriel. Wastewater Microbiology $3^{\text {rd }}$ ed. Chichester, John Wiley \& Sons, 2005. 768 p. ISBN 978-0471-65071-3.

CHA, J.M.; CHA, W.S. and LEE, J.H. Removal of organosulphur odour compounds by Thiobacillus novellas SRM, sulphur-oxidizing microorganisms. Process Biochemistry, 1999, vol. 34, no. 6-7, p. 659-665.

CHEN, X.G.; GENG, A.L.; YAN, R.; GOULD, W.D.; NG, Y.L. and LIANNG, D.T. Isolation and characterization of sulphur-oxidizing Thiomonas sp. and its potential application in biological deodorization. Letters in Applied Microbiology, 2004, vol. 39, no. 6, p. 495-503.

CHUNG, Y.C.; HO, K.L. and TSENG, C.P. Hydrogen sulfide gas treatment by a chemical-biological process: chemical absorption and biological oxidation steps. Journal of Environmental Science Health Part B, 2003, vol. 38, no. 5, p. 663-679.

DSMZ. List of media. Deutsche Sammlung zon Mikroorganismen und Zellkulturen Gmbh (German Collection of Microorganisms and Cell Cultures) Germany, 2002.

GONZALEZ SANCHEZ, A.; ALCANTARA, S.; RAZOFLORES, E. and REVAH, S. Oxygen transfer and consumption in a thiosulfate oxidizing bioreactor with sulfur production. Letters in Applied Microbiology, 2005, vol. 41, no. 2, p. 141-146. 
JIANG, H-X.; WANG, S-H.; XUE, Q-J. and YAN, Y-C. Isolation, identification and characterization of a methylparathion degrading bacterium. Journal of AgroEnvironment Science, 2005, vol. 24, p. 962-965.

KANTACHOTE, D. and INNUWAT, W. Isolation of Thiobacillus sp. for use in treatment of rubber sheet wastewater. Songklanakarin Journal of Science and Technology, 2004, vol. 26, no. 5, p. 649-657.

KANTACHOTE, D.; TORPEE, S. and UNSAKUL, K. The potential use of anoxygenic phototrophic bacteria for treating latex rubber sheet wastewater. Electronic Journal of Biotechnology, 2005, vol. 8, no. 3, p. 314-323.

KATAYAMA, Y.; UCHINO, Y.; WOOD, A.P. and DONOVAN, P.K. Confirmation of Thiomonas delicata (formerly Thiobacillus delicatus) as a distinct species of the genus Thiomonas Moreira and Amils 1997 with comments on some species currently assigned to the genus. International Journal of Systematic and Evolutionary Microbiology, 2006, vol. 56, p. 2553-2557.

KELLY, D.P. and HARRISON, A.P. Genus Thiobacillus. In: STALEY, J.T. ed. Bergey's Manual of Systematic Bacteriology. Baltimore, Williams \& Wilkins, 1989, vol. 3, p. $1842-1858$.

KERSTERS, K. and LEY, J.D. Genus Alcaligenes. In: KRIEG, N.R. ed. Bergey's Manual of Systematic Bacteriology. Baltimore, Williams \& Wilkins, 1984. vol. 1, p. 361-373.

KHANAL, S.K. and HUANG, J.C. Anaerobic treatment of high sulfate wastewater with oxygenation to control sulfide toxicity. Journal of Environmental Engineering, December 2003, vol. 129, no. 12, p. 1104-1111.

KLEEREBEZEM, R. and MENDEZ, R. Autotrophic denitrification for combined hydrogen sulfide removal from biogas and post-denitrification. Water Science and Technology, 2002, vol. 45, no. 10, p. 349-56.

KUENEN, J.G.; ROBERTSON, L.A. and TUOVINEN, O.H. The genera Thiobacillus, Thiomicrospira and Thiosphaera. In: BALOWS, A.; TRUPER, H.G.; DWORKI, M.; HARDER,W. and SCHLEIFER, K.Hed. The Prokaryotes. New York. Springer-Verlag 1992, vol. 3, p. 2636-2657.

MARKL, H. Modeling of biogas reactors. In: WINTER, J. ed. Biotechnology. $2^{\text {nd }}$ New York: A Wiley Company, 1999, vol. 11a, p. 527-560.

MOREIRA, D. and AMILS, R. Phylogeny of Thiobacillus cuprinus and other mixotrophic Thiobacilli: proposal for Thiomonas gen. nov. International Journal of Systematic Bacteriology, April 1997, vol. 47, no. 2, p. 522-528.
OYARZUN, P.; ARANCIBIA, F.; CANALES, C. and AROCA, G.E. Biofiltration of high concentration of hydrogen sulphide using Thiobacillus thioparus. Process Biochemistry, 2003, vol. 39, p. 165-170.

PARK, D.H.; CHA, J.M.; RYU, H.W.; LEE, G.W.; YU, E.Y.; RHEE, J.I.; PARK, J.J.; KIM, S.W.; LEE, I.W.; JOE, Y.I.; RYU, Y.W.; HUR, B.K.; PARK, J.K. and PARK, K. Hydrogen sulfide removal utilizing immobilized Thiobacillus sp. IW with Ca-alginate bead. Biochemical Engineering Journal, 2002, vol. 11, no. 2-3, p. 167-173.

POTIVICHAYANON, S.; POKETHITIYOOK, P. and KRUATRACHUE, M. Hydrogen sulfide removal by a novel fixed-film bioscrubber system. Process Biochemistry, 2006, vol. 41, no. 3, p. 708-715.

SANTEGOEDS, C.M.; DAMGAARD, L.R.; HESSELINK, G.; ZOPFI, J.; LENS, P.; MUYZER, G. and BEER, D. Distribution of sulfate-reducing and methanogenic bacteria in anaerobic aggregates determined by microsensor and molecular analyses. Applied Environmental Microbiology, October 1999, vol. 65, no. 10, p. 4618-4629.

SUBLETTE, K.L.; KOLHATKAR, R. and RATERMAN, $\mathrm{K}$. Technological aspects of the microbial treatment of sulfide-rich wastewaters: a case study. Biodegradation, 1998, vol. 9, no. 3-4, p. 259-271.

TEKASAKUL, P. and TEKASAKUL, S. Environmental problems related to natural rubber production in Thailand. Journal of Aerosol Research, 2006, vol. 21, no. 2, p. 122129.

VAN TRAPPEN, S.; TAN, T.L.; SAMYN, E. and VANDAMME, P. Alcaligenes aquatilis sp. nov., a novel bacterium from sediments of the Weser Estuary, Germany, and a salt march on Shem Creek in Charleston Harbor, USA. International Journal of Systematic Evolutionary Microbiology, November 2005, vol. 55, no. 6, p. 25712575. 


\section{APPENDIX}

\section{FIGURES}

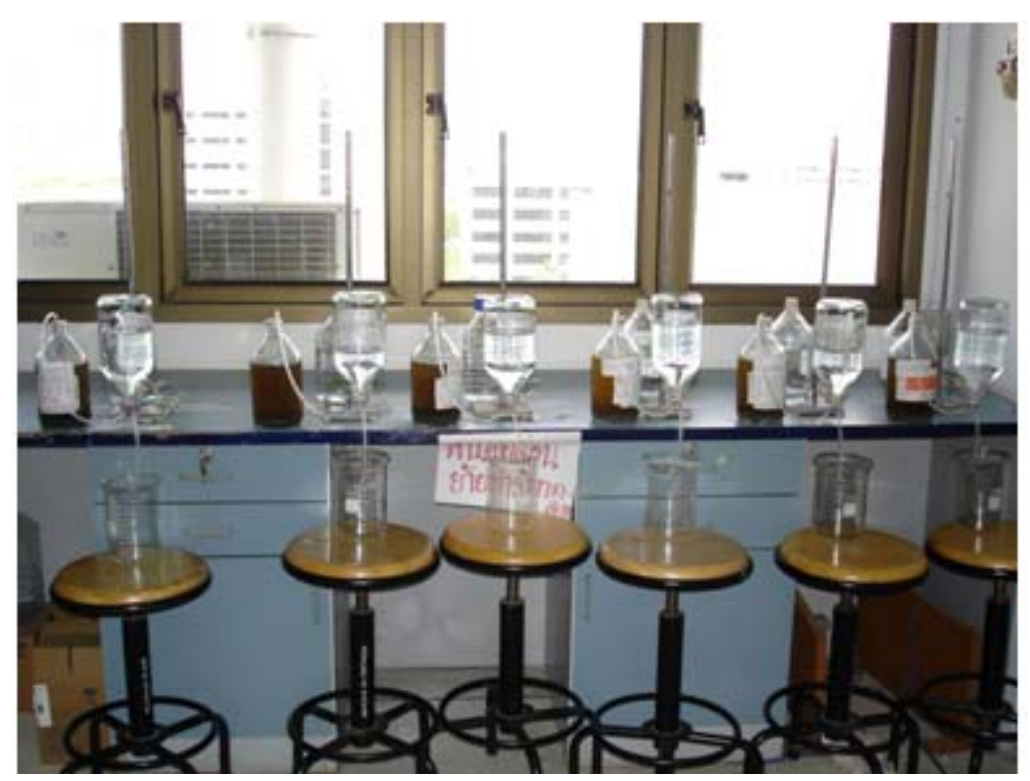

Figure 1. An experiment set of biogas production and gas collection apparatus.

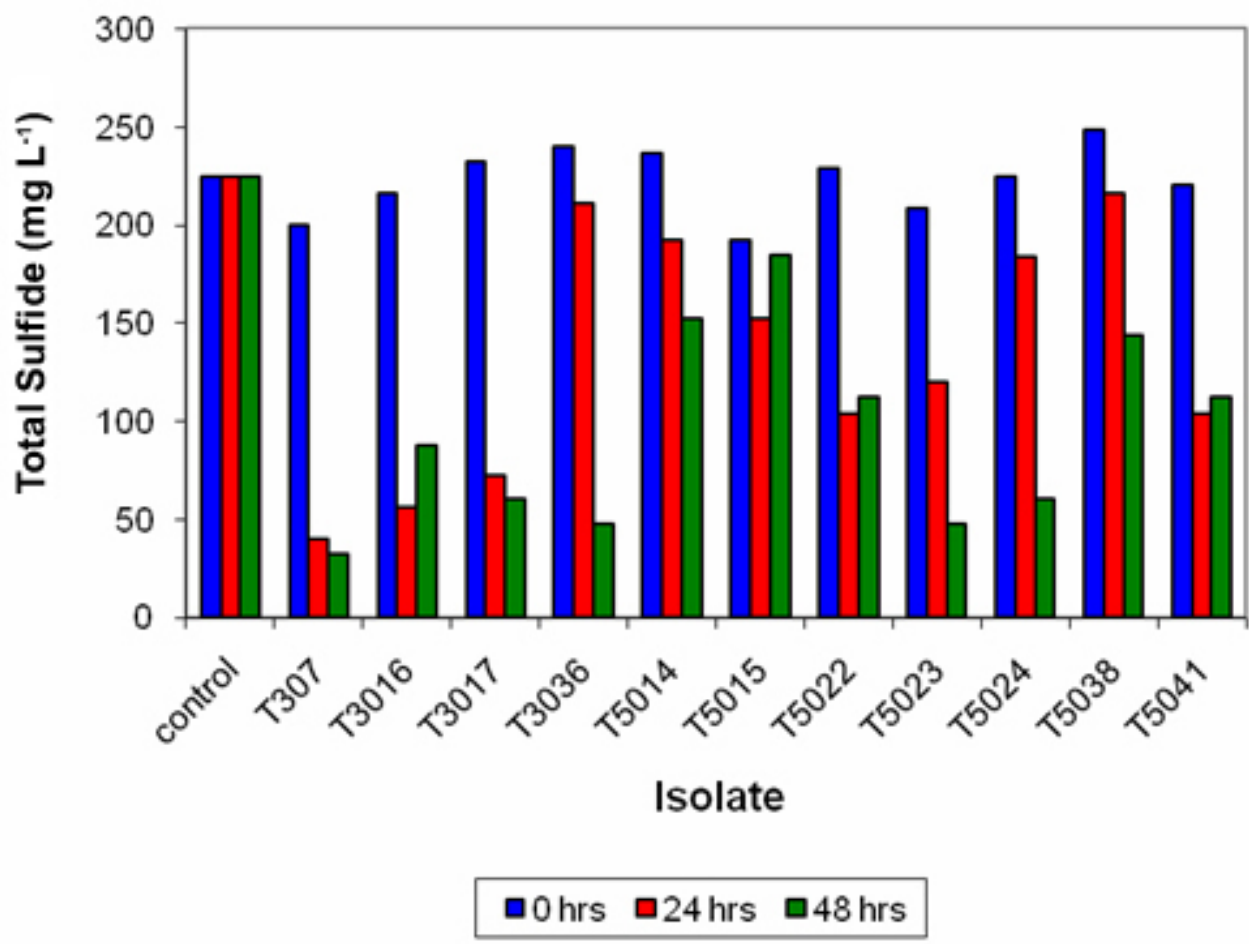

Figure 2. Reduction of total sulfide in effluent from a sulfate reduction reactor by sulfur oxidizing bacteria. 
Selection of sulfur oxidizing bacterium for sulfide removal in sulfate rich wastewater to enhance biogas production

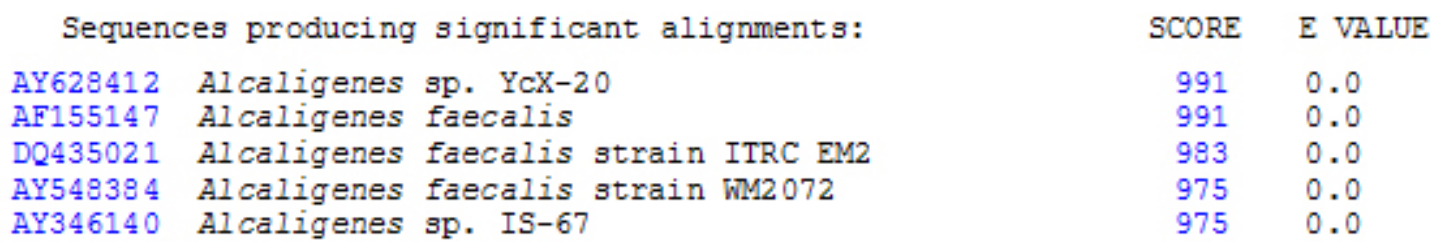

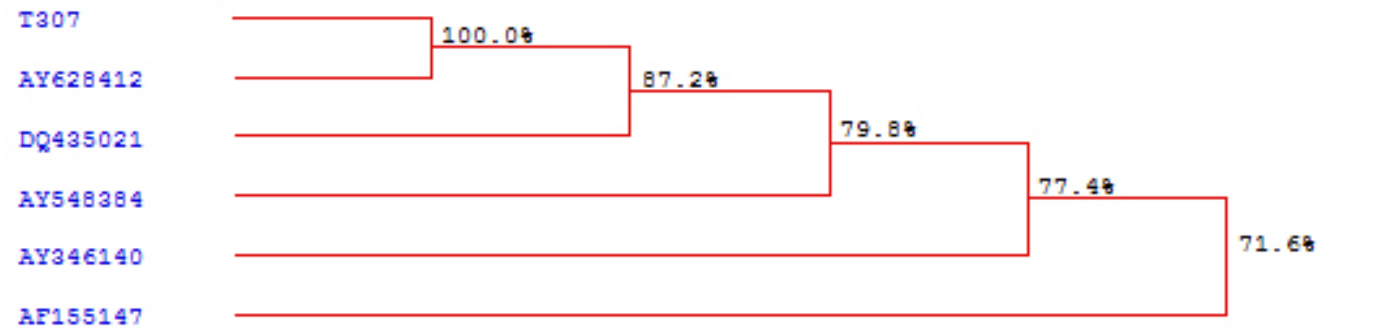

Figure 3. Phylogenic tree inferred from a comparison of 16S rRNA gene sequences, showing relationships between the isolate T307 and other species of Alcaligenes sp. 
Kantachote, D. et al.

Table 1. Characteristic of sulfur oxidizing bacterium isolate T307.

\begin{tabular}{|c|c|c|c|}
\hline Characteristic & T307 & Alcaligenes sp. ${ }^{a}$ & Thiobacillus delicatus $^{\mathrm{b}}$ \\
\hline Cell shape $($ size: $\mu \mathrm{m})$ & Short rod $(0.5 \times 0.9)$ & $\operatorname{Rod}(0.5-1.0 \times 0.5-2.6)$ & Short rod $(0.4-0.6 \times 0.7-1.6)$ \\
\hline Cell arrangement & single, rarely in pairs & Single, rarely in pairs & Single, rarely in pairs \\
\hline Motility & Non motile & Motile & Non motile \\
\hline Catalase & + & + & + \\
\hline Oxidase & + & + & - \\
\hline Facultative anaerobe $^{c}$ & + & V & V \\
\hline Chemolithotroph & + & + & + \\
\hline Mixotroph & + & + & + \\
\hline Chemoorganotroph & + & + & + \\
\hline Nitrate reduction & - & $\mathrm{V}$ & - \\
\hline Growth at 4 and $42^{\circ} \mathrm{C}$ & $+/+$ & $+/+$ & $-/+\left(15-42^{\circ} \mathrm{C}\right)$ \\
\hline Optimum temperature $\left({ }^{\circ} \mathrm{C}\right)$ & $25-30$ & $20-37$ & $30-35$ \\
\hline Growth at $\mathrm{pH} 2-4$ & - & ND & - \\
\hline Growth range: $\mathrm{pH}$ & $5-9$ & ND & $5.0-7.0$ \\
\hline Optimum pH & 7.0 & 7 & $5.5-6$ \\
\hline Fructose & $(+)$ & $\mathrm{V}$ & $(+)$ \\
\hline Maltose & - & V & $(+)$ \\
\hline Sucrose & - & $\mathrm{V}$ & ND \\
\hline Lactose & - & V & ND \\
\hline Mannitol & - & $\mathrm{V}$ & ND \\
\hline Arginine & - & V & ND \\
\hline Hydrolysis of starch & - & $\mathrm{V}$ & ND \\
\hline Sodium acetate & + & + & ND \\
\hline Sodium formate & + & ND & ND \\
\hline \multicolumn{4}{|l|}{ API 20E, Biomerieux } \\
\hline Citrate & - & + & + \\
\hline Indole & - & - & ND \\
\hline Voges-Proskauer & - & ND & ND \\
\hline $\mathrm{H}_{2} \mathrm{~S}$ production & - & - & ND \\
\hline Urease & + & $\mathrm{V}$ & + \\
\hline Gelatin & + & V & ND \\
\hline O-F (glucose) & $-1-$ & V & $-1-$ \\
\hline Mannose & - & $\mathrm{V}$ & ND \\
\hline Arabinose & - & $\mathrm{V}$ & ND \\
\hline Amygdalin & - & - & ND \\
\hline Saccharose & - & - & ND \\
\hline Rhamnose & - & V & ND \\
\hline Sorbitol & - & V & ND \\
\hline Inositol & - & V & ND \\
\hline Ornithine decarboxylase & - & V & ND \\
\hline Lysine decarboxylase & - & V & ND \\
\hline Tryptophan deaminase & - & $\mathrm{V}$ & ND \\
\hline
\end{tabular}

${ }^{\mathrm{a}}$ Code from Kerster and Ley, $1984,{ }^{\mathrm{b}}$ Code from Kelly and Harrison, $1989,{ }^{\mathrm{C}}$ mixotrophic and chemolithotrophic media with thiosulfate, $(+)=$ weakly positive, $\mathrm{ND}=$ not determined, $\mathrm{V}=$ Variable depending on species/strain. 
Table 2. Specific growth rates of isolate T307 at different values of yeast extract, $\mathrm{pH}$ and temperature. TSY medium was used for investigation effects of $\mathrm{pH}$ and temperature on bacterial growth.

\begin{tabular}{|c|c|c|c|c|c|}
\hline \multicolumn{6}{|c|}{ Variable Factor } \\
\hline $\begin{array}{l}\text { \%Yeast extract in } \\
\text { thiosulfate MSM }\end{array}$ & $\mu\left(h^{-1}\right)$ & $\mathrm{pH}^{\mathrm{a}}$ & $\mu\left(h^{-1}\right)$ & Temperature $\left({ }^{\circ} \mathrm{C}\right)^{\mathrm{b}}$ & $\mu\left(h^{-1}\right)$ \\
\hline 0 & $0.015 \pm 0.001$ & 6.0 & $0.120 \pm 0.004$ & 25 & $0.137 \pm 0.004$ \\
\hline 0.05 & $0.096 \pm 0.002$ & 6.5 & $0.126 \pm 0.002$ & 30 & $0.138 \pm 0.002$ \\
\hline 0.10 & $0.138 \pm 0.003$ & 7.0 & $0.138 \pm 0.001$ & 35 & $0.118 \pm 0.002$ \\
\hline 0.15 & $0.179 \pm 0.002$ & 7.5 & $0.133 \pm 0.002$ & 40 & $0.100 \pm 0.009$ \\
\hline \multirow[t]{3}{*}{0.20} & $0.234 \pm 0.001$ & 8.0 & $0.119 \pm 0.003$ & & \\
\hline & & 8.5 & $0.117 \pm 0.004$ & & \\
\hline & & 9.0 & $0.113 \pm 0.006$ & & \\
\hline
\end{tabular}

${ }^{\mathrm{a}}$ Temperature incubation at $30^{\circ} \mathrm{C},{ }^{\mathrm{b}}$ Initial $\mathrm{pH}$ at 7.

$\mu$ : mean value and standard deviation of three determinations.

Table 3. Removal of sulfide in the effluent from SRR by Alcaligenes sp. T307.

\begin{tabular}{|c|c|c|c|c|}
\hline \multirow[t]{2}{*}{ Parameter $\left(\mathrm{mg} \mathrm{L}^{-1}\right)^{*}$} & \multicolumn{2}{|c|}{$\begin{array}{l}\text { Sterile optimized wastewater } \\
\text { (SOW: pure culture) }\end{array}$} & \multicolumn{2}{|c|}{$\begin{array}{l}\text { Raw optimized wastewater } \\
\text { (ROW: mixed cultures) }\end{array}$} \\
\hline & $0 \mathrm{hr}$ & $20 \mathrm{hrs}$ & $0 \mathrm{hr}$ & $20 \mathrm{hrs}$ \\
\hline BOD & $503 \pm 12$ & $483 \pm 10$ & $553 \pm 15$ & $575 \pm 17$ \\
\hline COD & $2500 \pm 24$ & $1533 \pm 18$ & $2450 \pm 21$ & $1533 \pm 15$ \\
\hline $\mathrm{BOD} / \mathrm{COD}$ & $0.20 \pm 0.003$ & $0.32 \pm 0.003$ & $0.23 \pm 0.004$ & $0.38 \pm 0.007$ \\
\hline VFAs & $222 \pm 8.6$ & $194 \pm 7.6$ & $210 \pm 7.3$ & $103 \pm 5.6$ \\
\hline $\mathrm{pH}$ & $6.96 \pm 0.18$ & $8.29 \pm 0.21$ & $6.97 \pm 0.15$ & $8.52 \pm 0.22$ \\
\hline $\begin{array}{l}\text { Viable cells } \\
\left({\left.\text { (cfu } \mathrm{ml}^{-1}\right)}^{\text {a }}\right.\end{array}$ & $8.41 \pm 0.21$ & $9.02 \pm 0.24$ & $8.16 \pm 0.19$ & $8.96 \pm 0.22$ \\
\hline Total sulfide & $19.6 \pm 1.4$ & $\begin{array}{r}1.6 \pm 0.14 \\
(91.84 \%)\end{array}$ & $18.9 \pm 1.2$ & $\begin{array}{c}8.27 \pm 0.32 \\
(56.24 \%)\end{array}$ \\
\hline Dissolved sulfide & $8.27 \pm 0.7$ & $\begin{array}{c}0.93 \pm 0.08 \\
(88.75 \%)\end{array}$ & $8.27 \pm 0.5$ & $\begin{array}{l}5.6 \pm 0.13 \\
(32.29 \%)\end{array}$ \\
\hline Hydrogen sulfide & $1.18 \pm 0.11$ & $\begin{array}{c}0.05 \pm 0.001 \\
(95.76 \%)\end{array}$ & $1.14 \pm 0.09$ & $\begin{array}{l}0.09 \pm 0.002 \\
(92.11 \%)\end{array}$ \\
\hline Sulfate & $498 \pm 9.5$ & $487 \pm 8.7$ & $485 \pm 7.9$ & $491 \pm 8.5$ \\
\hline
\end{tabular}

*Unless stated, mean value and standard deviation of three determinations. 
Table 4. Removal of sulfide in sulfide medium prior to biogas production.

\begin{tabular}{|c|c|c|c|c|}
\hline \multirow{2}{*}{$\begin{array}{l}\text { Parameter } \\
\left(\mathrm{mg} \mathrm{L}^{-1}\right)^{*}\end{array}$} & \multicolumn{2}{|c|}{ Abiotic control } & \multicolumn{2}{|c|}{ Alcaligenes sp. T307 } \\
\hline & 0 hrs & 20 hrs & 0 hrs & 20 hrs \\
\hline $\mathrm{pH}$ & $7.30 \pm 0.23$ & $7.32 \pm 0.26$ & $7.33 \pm 0.18$ & $8.44 \pm 0.21$ \\
\hline Viable cells $\left(\mathrm{cfu} \mathrm{m}^{-1}\right)$ & 0 & 0 & $8.36 \pm 0.15$ & $9.72 \pm 0.18$ \\
\hline Total sulfide (TS) & $71.1 \pm 1.3$ & $72 \pm 1.5$ & $72.1 \pm 1.4$ & $\begin{array}{c}12.1 \pm 0.15 \\
(83.22 \%)\end{array}$ \\
\hline Dissolved sulfide & $61.6 \pm 0.56$ & $62.1 \pm 0.61$ & $60.6 \pm 0.47$ & $\begin{array}{c}17.1 \pm 0.31 \\
(71.78 \%)\end{array}$ \\
\hline Hydrogen sulfide $\left(\mathrm{H}_{2} \mathrm{~S}\right)$ & $0.74 \pm 0.09$ & $0.63 \pm 0.07$ & $0.73 \pm 0.08$ & $\begin{array}{c}0.07 \pm 0.002 \\
(90.41)\end{array}$ \\
\hline Sulfate & $456 \pm 6.8$ & $468 \pm 7.3$ & $442 \pm 5.7$ & $449 \pm 5.5$ \\
\hline
\end{tabular}

*Unless stated, mean value and standard deviation of four determinations

Table 5. Effect of sulfide removal by Alcaligenes sp. T307 in sulfide medium on biogas production over 5 days incubation.

\begin{tabular}{|c|c|c|}
\hline Parameter $\left(\mathrm{mg} \mathrm{L}^{-1}\right)^{*}$ & Control & Pre-treated by T307 \\
\hline Effluent $\mathrm{pH}$ & $8.76 \pm 0.28$ & $8.37 \pm 0.10$ \\
\hline Effluent total sulfide & $70.8 \pm 1.70$ & $12.1 \pm 0.20$ \\
\hline Effluent dissolved sulfide & $14.7 \pm 0.57$ & $10.0 \pm 0.27$ \\
\hline Effluent $\mathrm{H}_{2} \mathrm{~S}$ & $1.0 \pm 0.15$ & $1.1 \pm 0.16$ \\
\hline Effluent sulfate & $100.5 \pm 6.36$ & $143 \pm 4.24$ \\
\hline Influent COD & $5790 \pm 61.47$ & $4890 \pm 49.1$ \\
\hline Effluent COD & $3670 \pm 56.57$ & $2465 \pm 39.5$ \\
\hline COD reduction (\%) & $36.62 \pm 0.98$ & $49.60 \pm 1.01$ \\
\hline Biogas produced $\left(\mathrm{ml} \mathrm{L}^{-1} \mathrm{~d}^{-1}\right)$ & $85.5 \pm 32.96$ & $240 \pm 24.86$ \\
\hline \multicolumn{3}{|l|}{ Biogas composition } \\
\hline$\% \mathrm{CH}_{4}$ & $35.47 \pm 12.99$ & $48.06 \pm 7.15$ \\
\hline$\% \mathrm{CO}_{2}$ & $63.67 \pm 13.29$ & $51.53 \pm 7.18$ \\
\hline$\% \mathrm{H}_{2} \mathrm{~S}$ & $0.86 \pm 0.69$ & $0.41 \pm 0.3$ \\
\hline Specific yield of $\mathrm{CH}_{4}\left(\mathrm{ml} \mathrm{g}^{-1} \mathrm{COD}\right.$ removed $)$ & $71.53 \pm 18$ & $237.81 \pm 17$ \\
\hline
\end{tabular}

*Unless stated, mean value and standard deviation of six determinations 